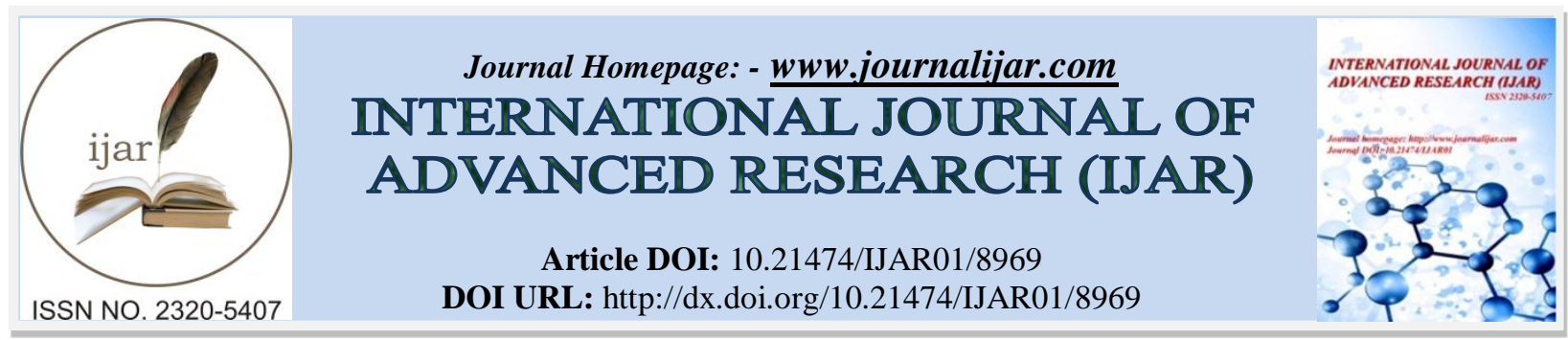

RESEARCH ARTICLE

\title{
ASPECT OF THE NEGLECTED BIOLOGY OF A JUVENILE CATFISH FROM THE WILD.
}

F. V. Oluwale.

Hydrobiology and Fisheries Unit, Department of Zoology, University of Ibadan, Ibadan, Nigeria.

\section{Manuscript Info}

Manuscript History

Received: 24 February 2019

Final Accepted: 26 March 2019

Published: April 2019

Key words:-

Diet, feeding strategy, length-weight

relations, form factor, Epe Lagoon.

\begin{abstract}
This study aimed at enhancing the production of Chrysichthys nigrodigitatus through neglected biology of its juveniles. Samples were procured monthly (June- November 2018) from fishermen landing site at Epe Lagoon. Altogether 240 specimens ranging from $3.9-101 \mathrm{~mm}$ Fork length $(M=12.52, S D=6.46)$ and weighed $4.83-40.2 \mathrm{~g}(M 15.2$, $S D=5.11)$ were examined. Regression coefficient $(\mathrm{b}=2)$ of length weight relationship indicated negative allometric growth. Estimated form factor $\left(\mathrm{a}_{3.0}\right)$ was 0.039 . Vacuity index value $(16 \%)$ purported edacious species. Stomach content analysis based on relative importance index revealed that juvenile $C$. nigrodigitatus were omnivorous subsisting primarily on algae, (55.94), chironomid larvae (51.20), amphipods (40.22), rotifer (38.56), plant (37.94), and fish fry (34.49). Appraised relative gut length was $>1$ validating omnivorous feeding habit. Feeding strategy plot depicted the species as generalist with insectivorous tendency. Juvenile Chrysichthys nigrodigitatus may thrive on insect protein when raise in culture enclosures.
\end{abstract}

Copy Right, IJAR, 2019,. All rights reserved.

\section{Introduction:-}

Virtually all the reports on the biology of the Bagrid catfish, Chrysichthys nigrodigitatus (Lacépède, 1803) in Nigeria waters are mostly limited to the adult life stage: food and feeding ecology (George and Atakpa, 2015); diet composition, feeding habits and condition factor (Uneke, 2014); condition factor and diet (Atobatele and Ugwumba, 2011); morphometry and diet (Lawal et al., 2010 ); food habits (Yem et al., 2009); food and feeding habits (Kusemiju and Olaniyan (1989); comparative studies of catfish for breeding purposes (Ezenwa et al., 1986); age and growth determination (Ezenwa and Kusemiju, 1981); taxonomic description (Reed et al., 1967). Consequently, the biology and ecology of the juvenile in the wild have been greatly neglected. Although $C$. nigrodigitatus is a commercial important fish that is widespread in Africa tropical waters (Boulenger, 1909-1915; Adite et al., 2006; Adite $e t a l$, 2017) where they grow and spawn actively, and also constitute one of the dominant catches of capture fishery by artisanal fishermen, it is quite difficult to reproduce C. nigrodigitatus in culture enclosures (Otémé, 1993) in order to supply aquaculture center with fingerlings or seeds (Houehanou et al, 2017). The primary source of seeds of this species for stocking culture enclosures still remains wild collection of juveniles from natural environment especially during the adult breeding season (Laleye et al. 1995) which coincides with the rainy and flood period. Poor advancement in propagation protocols for this species maybe due partly to inadequate biological information on the juvenile stages that is often collected for grow-out in captive conditions.

Natural populations of Chrysichthys nigrodigitatus in Nigeria freshwater ecosystems are on decline possibly due to the increasing demand for its high-protein-content hardy flesh. Clear evidence that the species is endangered in some 
part of Nigeria was portrayed by Ayotunde and Ada (2013) in Cross River, Cross River State. Chrysichthys nigrodigitatus is one of the most threatened fish species with the highest rate of extinction (Araoye, 1999; Craig 2000). Some of the educed reasons for declining population of stocks of this species in the wild include increasing higher demand, habitat loss and degradation, pollution (Ayotunde and Ada, 2013), environmental degradations, overfishing (Asuquo et al., 2013). Adite et al. (2006) pointed out that the biology of $C$. nigrodigitatus has not been extensively studied despite its acute decreasing population. There is an urgent need for conservation efforts on this species to reverse the acute decreasing population of the species in Nigerian freshwater ecosystems. Deficiency of the early life stages is one of the primary constraints for intensive production of this species (Ayotunde and Ada, 2013). There is limited scientific information on artificial reproduction, captive breeding and early life stages of Chrysichthys nigrodigitatus in Nigeria. Biological information on early life stages of fish especially the juvenile is essential for sustainable exploitation, conservation, rational fisheries management and provision of seeds for culture centers (Adite el al., 2017).

The present study is aimed at enhancing the production of Chrysichthys nigrodigitatus through basic information on neglected biology of its juvenile. Biological data is required for sustainable exploitation and appropriate utilization of fish stock. Aspects of the biology of this stage covered include diet composition, feeding strategy, gut morphology, length-weight relationship and form factor. For instance, in fish as in other animals, food supplies are basic governing factors for growth rate, condition, abundance, movement and fertility. Adequate knowledge of feeding habits of a fish species is essential for proffering solutions for evolving challenges to human exploitation of fish resources.

\section{Materials and methods:-}

Study area

Epe Lagoon with a surface area of about $243 \mathrm{~km}^{2}$ (FAO, 1969) and a maximum depth of about $6 \mathrm{~m}$ lies between longitude $\mathrm{N} 06^{\circ} 33.710^{\prime} \mathrm{E} 004^{\circ} 03^{\prime} .710^{\prime}$ and latitudes $\mathrm{N} 06^{\circ} 31.893^{\prime} \mathrm{E} 003^{\circ} 31.912^{\prime}$. The lagoon is a freshwater ecosystem sandwiched between two lagoons, Lekki lagoon (freshwater) in the east and Lagos lagoon (brackish) in the south with the Osun River being the main river discharging into the lagoon. The climate is classified as tropical with dry season occurring between December and April and the rainy season concentrated between May and November. The rainy season is associated with the breeding period of several important commercial fish species inhabiting the lagoon including Chrysichthys nigrodigitatus, when the lagoon serves as the nursery and feeding ground for the pre-juvenile and juvenile stages of such species. The lagoon supports thriving commercial fisheries in Lagos and Ogun States, Nigeria.

\section{Collection of samples of Chrysichthys nigrodigitatus juveniles}

Random samples of Chrysichthys nigrodigitatus juveniles (Figure 2) were procured from artisanal fishermen at Chief landing site of fishermen from Epe Lagoon. The specimens were caught with Cast and Set nets. Samples were collected monthly between June and November, 2017, chilled in ice-chest containing ice cubes and transported to the laboratory where they were preserved by deep freezing $\left(-4^{0} \mathrm{C}\right)$ prior to further examination.

\section{Data collection}

In the laboratory, preserved specimens were thawed and mopped dry using tissues paper. Fish samples were sorted in order to remove juveniles of other species erroneously collected with the sample and identified according to Olaosebikan and Raji (1988). Forked length (precision $=0.1 \mathrm{~mm}$ ) and whole body wet weight (precision $=0.1 \mathrm{~g}$.) of individual specimen in the sample were measured. Stomach was removed after internal dissection of the body and preserved in 5\% neutralized formalin. Feeding intensity of Chrysichthys nigrodigitatus juvenile was assessed by using Vacuity index (VI) after examination of stomach by visual inspection. Vacuity index (VI) expressed the fraction of a fish population with food in their stomach, it was determined according to Euzen (1987) by:

$\mathrm{VI}=\underline{\mathrm{E}_{\underline{s}}} \underline{\mathrm{X} 100}$

$T_{s}$ 


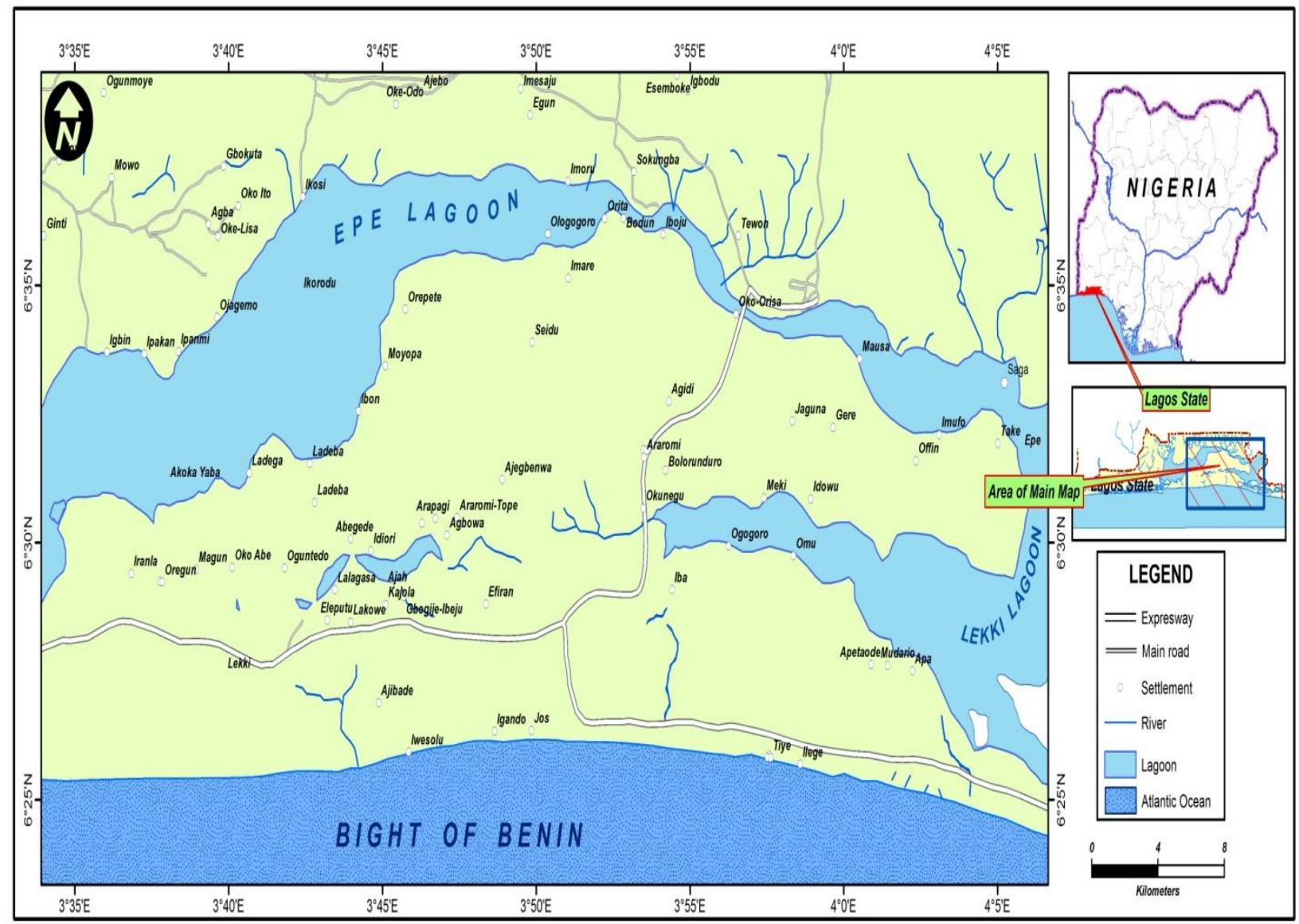

Figure 1: Epe Lagoon

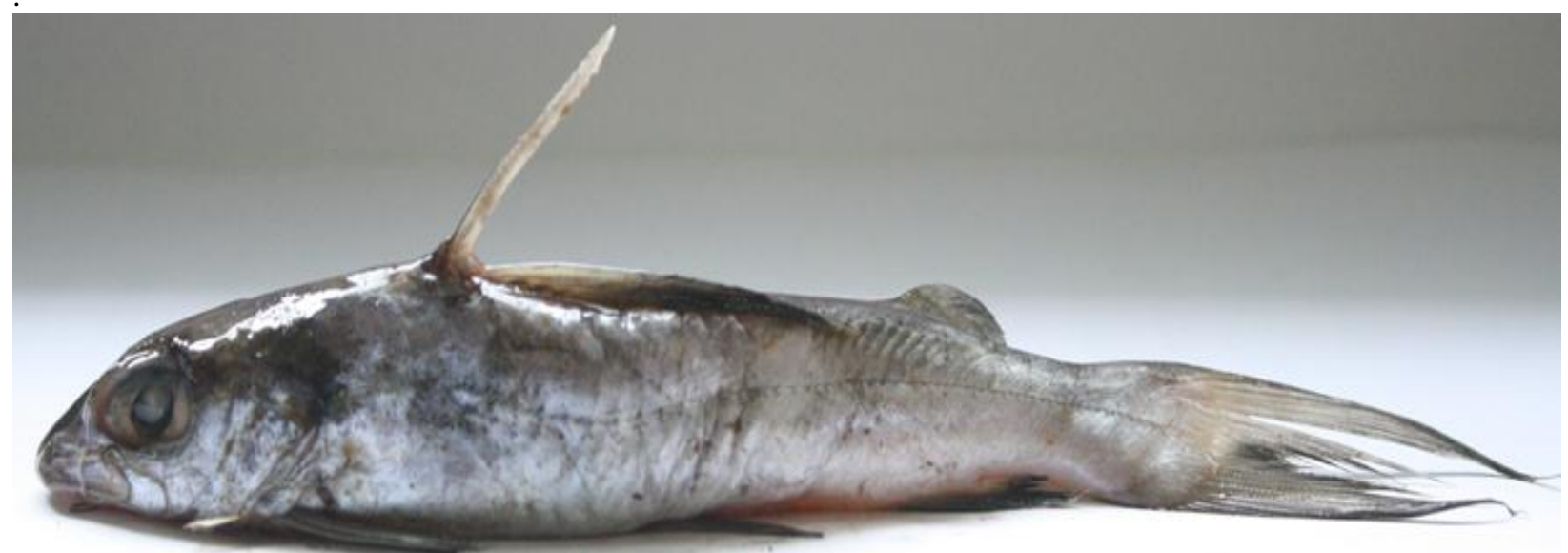

Figure 2: Chrysichthys nigrodigitatus

where $E_{s}=$ number of empty stomach samples; $T_{s}=$ total number of stomach samples. Values of feeding intensity based on VI are usually interpreted as follows: - edacious species $0 \leq \mathrm{VI}<20$; relatively edacious species $20 \leq \mathrm{VI}<$ 40 ; relatively abstemious $60 \leq \mathrm{VI}<80$ and abstemious $80 \leq \mathrm{VI}<100$.

Stomach contents of preserved stomachs were emptied into a Petri dishes, kept for 3 minutes to remove excess formalin. Each of the food items was identified to the lowest possible taxonomic level. Quantitative analysis of stomach consents was done by using numerical, frequency of occurrence and volumetric (water displacement) methods (Hyslop, 1980). Index of Relative Importance (IRI), an integrated measurement of number, frequency of 
occurrence and volume, was used to present a less biased food items in the stomach. It was calculated by adding the numerical and volumetric percentages values and multiplying with frequency of occurrence percentage value (Pinkas et al., 1971). This was based on assertions that such a compound index (an index comprising any of the traditional methods including numerical, frequency of occurrence and volumetric et cetera) eliminate biases inherent in any of the aforementioned traditional methods (Chipps and Garvey, 2002). Further, it captures more information than any of the basic index use in isolation.

Gut lengths of specimens were measured with a ruler (precision $0.1 \mathrm{~mm}$ ) after internal dissection. The Relative Gut Length (RGL) was expressed as the ratio of total length of gut to total body length (Biswas, 1993):

$$
\text { RGL }=\frac{\text { Total length of gut }}{\text { Total length of fish }}
$$

where fish can be classified as herbivorous (RLG>1), carnivorous ( $R L G<1)$ or omnivorous $(\mathrm{RLG}=$, or $>$, or $<1$ ) (Biswas, 1993).

Prior to determination of feeding strategy of the species, dietary items encountered in the stomach were expressed in higher taxa grouping for ease of comparison (Bowen, 1984). The graphical method (Amundsen et al. 1996) was used to determine the feeding strategy of the species. This was based on a two-dimensional depiction of plots of Prey Specific Abundance, $\mathrm{P}_{\mathrm{i}}$ (Y-axis) against frequency of occurrence in fraction not percentages (X-axis). The prey specific abundance is a measure of relative abundance of food items encountered in the stomach based on bulk (volume); and it was calculated as:

$\mathrm{P}_{\mathrm{i}}=\frac{\sum \mathrm{S}_{\mathrm{i}} \times 100}{\sum \mathrm{S}_{\mathrm{t}}}$

where: $P_{i}=$ prey specific abundance, $S_{i}=$ volume of prey i in stomachs, and $S_{t}=$ total volume of stomach contents in only those individuals with prey $\mathrm{i}$ in the stomachs. Interpretation of the diagram is based on distribution of points along the diagonals and axes of the graph to indicate feeding strategy, prey importance and niche breadth of the species (Amundsen et al. 1996).

The relationship between forked body length and total body wet weight was estimated from the equation: $\mathrm{W}=\mathrm{aL}^{\mathrm{b}}$ (Pauly 1984).

$\mathrm{W}=$ weight of fish in grams, $\mathrm{L}=$ fork length of fish in millimeters, "a" is proportionality constant and " $b$ " is the allometric coefficient both estimated by method of least squares (Lagler 1956) using logarithmically transformed expression;

$\log \mathrm{W}=\log \mathrm{a}+\mathrm{b} \log \mathrm{L}$.

The form factor $\left(\mathrm{a}_{3.0}\right)$ for $C$. nigrodigitatus juvenile was calculated using the empirical equation given by Froese (2006) as: $\mathrm{a}_{3.0}=10^{\log \mathrm{a}-\mathrm{s}(\mathrm{b}-3) \text {, }}$

where $\mathrm{a}$ and $\mathrm{b}$ are regression parameters of length-weight relationship of the species and $\mathrm{S}$ is the regression slope of $\log$ a vs. b. A mean slope $S=-1.358$ (Froese 2006) was used for estimating the form factor because of dearth of information on $C$. nigrodigitatus juvenile for estimation of the regression $(S)$ of $\ln$ a vs. b.

\section{Statistical analysis}

Statistical analyses were performed using Microsoft® Excel 2007 and GraphPad Prism 5 for Windows, GraphPad Software, San Diego California USA, www.graphpad.com. All statistical analyses were considered significant at 5\% $(\mathrm{p}<0.05)$. Descriptive statistics (mean, standard deviation) was used to summarize body parameter of fish data using Microsoft excel; and also for computation of proportion and percentages of dietary items. Correlation and linear regression were performed using GraphPad Prism Version 5.00. Amundsen plots of feeding strategy was plotted using Microsoft excel spreadsheet coded with Macro command 2007.

\section{Results:-}

\section{Juvenile Chrysichthys nigrodigitatus}

Overall 240 specimens of juvenile Chrysichthys nigrodigitatus were examined during the present study. Fork length of $C$. nigrodigitatus juvenile collected from Epe Lagoon ranged from $3.9-101 \mathrm{~mm}(M=12.52, S D=6.46)$. Body weight ranged $4.83-40.2 \mathrm{~g}(M 15.2, S D=5.11)$. 


\section{Diet composition}

Vacuity index value of $16 \%$ was revealed from analysis of stomach contents Chrysichthys nigrodigitatus juveniles from Epe Lagoon. Twenty-seven food items were found in the stomach of $C$. nigrodigitatus juvenile, which are categorized mainly as zooplankton, crustacean, decapoda, insect, osteichthyes, algae, and plant materials (Table 1). Analysis of stomach contents based on primary indices (Table 1) revealed that micro-crustaceans namely Daphnia sp. $(8.09 \%)$ and Copepoda $(7.69 \%)$ were the most important food items based on \% numerical and frequency of occurrence methods respectively. Chironomid larvae, an insect, were the most important food by \% volumetric method. Based on the relative importance index (Figure 3), the primary foods of C. nigrodigitatus juvenile were algae (55.9), chironomid larvae (51.2), amphipods (40.2), rotifers (38.6), plant materials (37.9) and fish fry (34.5). The most important food category in the diet also based on the relative important index (Figure 4) was insects followed closely by micro-crustacean.

\section{Relative gut length}

The estimated relative gut length was 1.25 .

\section{Feeding strategy}

The feeding strategy plot (Figure 5) revealed juvenile Chrysichthys nigrodigitatus from Epe Lagoon are generalist with an inclination as specialist predominantly on insect. The plot also indicated that the most dominant foods for this life stage of the species were insects while decapods crustaceans were the rarest. Plantyhelminths although encounter in the stomach may not being a food item.

Table 1:- Summary of stomach contents of juvenile Chrysichthys nigrodigitatus from Epe Lagoon

\begin{tabular}{|c|c|c|c|c|c|}
\hline Food items & & $\begin{array}{l}\text { Number }(\mathrm{N} \\
\%)\end{array}$ & $\begin{array}{l}\text { Frequency } \\
\text { Occurrence } \\
(\mathrm{FO} \%)\end{array}$ & $\begin{array}{l}\text { Volumetric }(\mathrm{V} \\
\%)\end{array}$ & $\begin{array}{l}\text { Index of } \\
\text { Relative } \\
\text { Importance } \\
\text { (IRI) }\end{array}$ \\
\hline \multicolumn{6}{|l|}{ Zooplankton } \\
\hline & Rotifera & 6.64 & 5.59 & 5.71 & 38.6 \\
\hline & Protozoans & 5.81 & 0.7 & 4.89 & 9.2 \\
\hline \multicolumn{6}{|l|}{ Arthropoda } \\
\hline \multicolumn{6}{|l|}{ Crustacean } \\
\hline & Copepoda & 7.47 & 7.69 & 2.45 & 26.3 \\
\hline & Ostracoda & 5.19 & 4.55 & 2.99 & 18.8 \\
\hline & Daphnia sp. & 8.09 & 3.5 & 1.9 & 14.7 \\
\hline & Mysids & 3.32 & 3.15 & 0.82 & 5.9 \\
\hline & Amphipods & 6.02 & 6.99 & 4.89 & 40.2 \\
\hline \multicolumn{6}{|l|}{ Decapoda } \\
\hline & Crab part & 2.07 & 3.15 & 3.126 & 12.3 \\
\hline & Prawn part & 1.24 & 1.05 & 1.63 & 3.0 \\
\hline \multicolumn{6}{|l|}{ Insecta } \\
\hline & Insect parts & 2.90 & 3.15 & 5.71 & 20.9 \\
\hline & $\begin{array}{l}\text { Chironomid } \\
\text { larvae }\end{array}$ & 4.36 & 5.94 & 7.88 & 51.2 \\
\hline & Insect nymphs & 3.32 & 3.50 & 7.61 & 29.9 \\
\hline & Notonecta sp. & 1.04 & 1.05 & 1.09 & 2.2 \\
\hline & Insect wings & 2.28 & 3.85 & 0.54 & 4.4 \\
\hline \multicolumn{6}{|l|}{ Osteichthyes } \\
\hline & Fish eggs & 6.22 & 6.29 & 2.45 & 21.6 \\
\hline & Fish fry & 4.56 & 5.24 & 5.71 & 34.5 \\
\hline \multicolumn{6}{|l|}{ Mollusca } \\
\hline & Gastropod shell & 3.11 & 2.45 & 5.16 & 15.7 \\
\hline & $\begin{array}{l}\text { Unidentified } \\
\text { bivalve }\end{array}$ & 1.24 & 1.05 & 8.15 & 9.8 \\
\hline & Anadara sp. & 0.83 & 1.40 & 2.45 & 4.3 \\
\hline & Bivalve larve & 2.28 & 3.15 & 4.89 & 17.1 \\
\hline
\end{tabular}




\begin{tabular}{|l|l|l|l|l|l|}
\hline Algae & & & & & \\
\hline & Navicula sp. & 1.04 & 1.75 & 1.09 & 2.9 \\
\hline & Synedra sp. & 0.83 & 0.7 & 0.54 & 1.2 \\
\hline & Spirogyra & 3.32 & 3.15 & 0.82 & 5.9 \\
\hline & Oscillatoria sp. & 4.15 & 4.20 & 1.36 & 9.9 \\
\hline & Spiriluna sp. & 1.87 & 2.10 & 0.82 & 3.6 \\
\hline & $\begin{array}{l}\text { Unidentified } \\
\text { algae }\end{array}$ & 5.39 & 6.64 & 7.61 & 55.9 \\
\hline Platyhelminths & & 1.66 & 1.75 & 2.17 & 5.5 \\
\hline Plant materials & & 3.73 & 6.29 & 5.43 & 37.9 \\
\hline
\end{tabular}

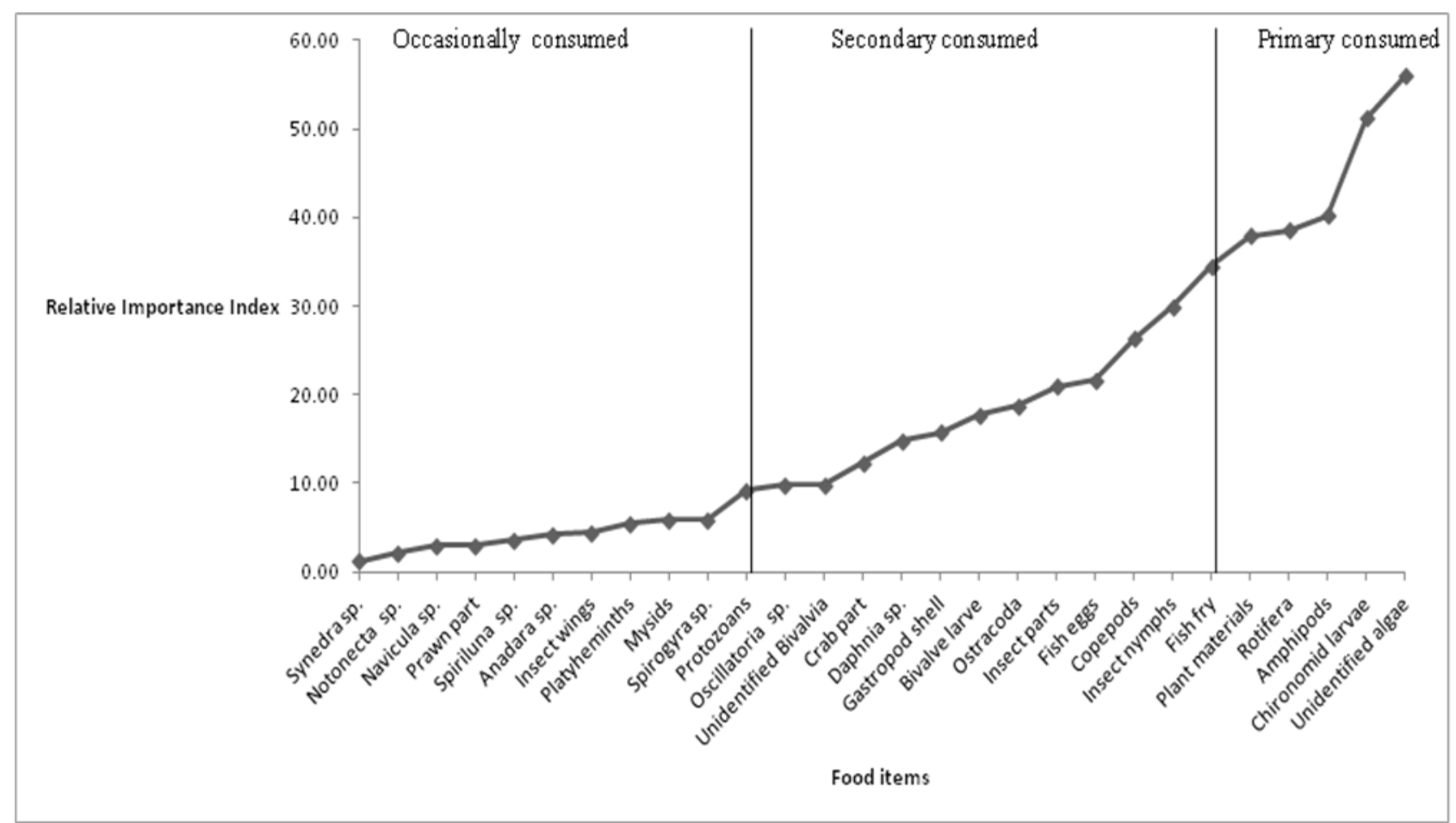

Figure 3: Diet preference of juvenile Chrysichthys nigrodigitatus from Epe Lagoon 


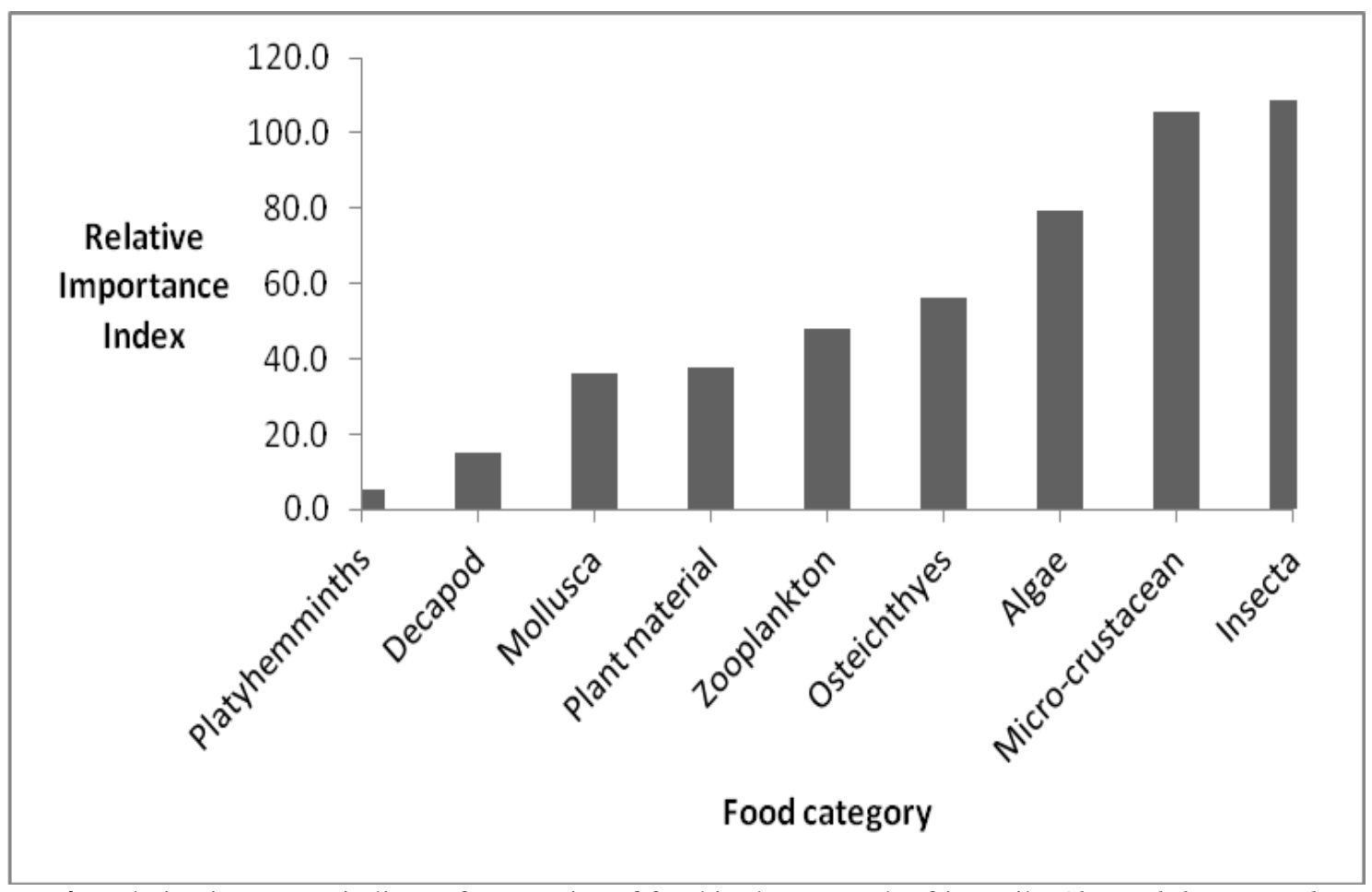

Figure 4: Relative important indices of categories of food in the stomach of juvenile Chrysichthys nigrodigitatus from Epe Lagoon.

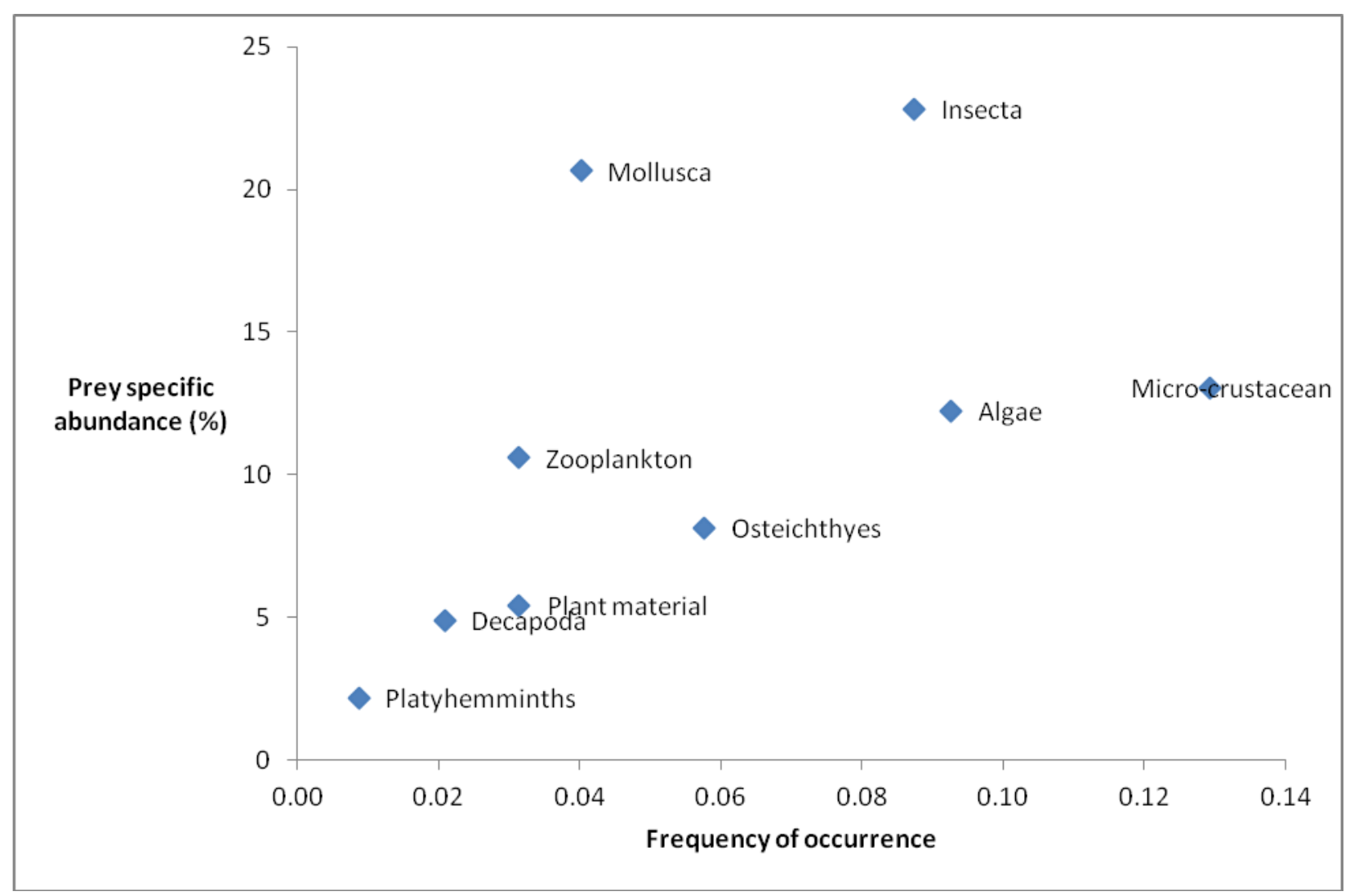

Figure 5: Feeding strategy of juvenile Chrysichthys nigrodigitatus 


\section{Length -weight relationship and form factor}

Forked length and body weight of juvenile Chrysichthys nigrodigitatus from Epe Lagoon were extremely significantly and positively correlated, $\mathrm{r}(240)=0.91, \mathrm{p}<0.001)$. The results of simple linear regression (Figure 6) indicated that weight could be predicted from length by the following formula: $Y=1.9568 x+0.0216, R^{2}=0.8351$. The regression growth coefficient $b=2$ shows negative allometric growth. The estimated form factor $\left(\mathrm{a}_{3.0}\right)$ was 0.039 for juvenile Chrysichthys nigrodigitatus in Epe Lagoon

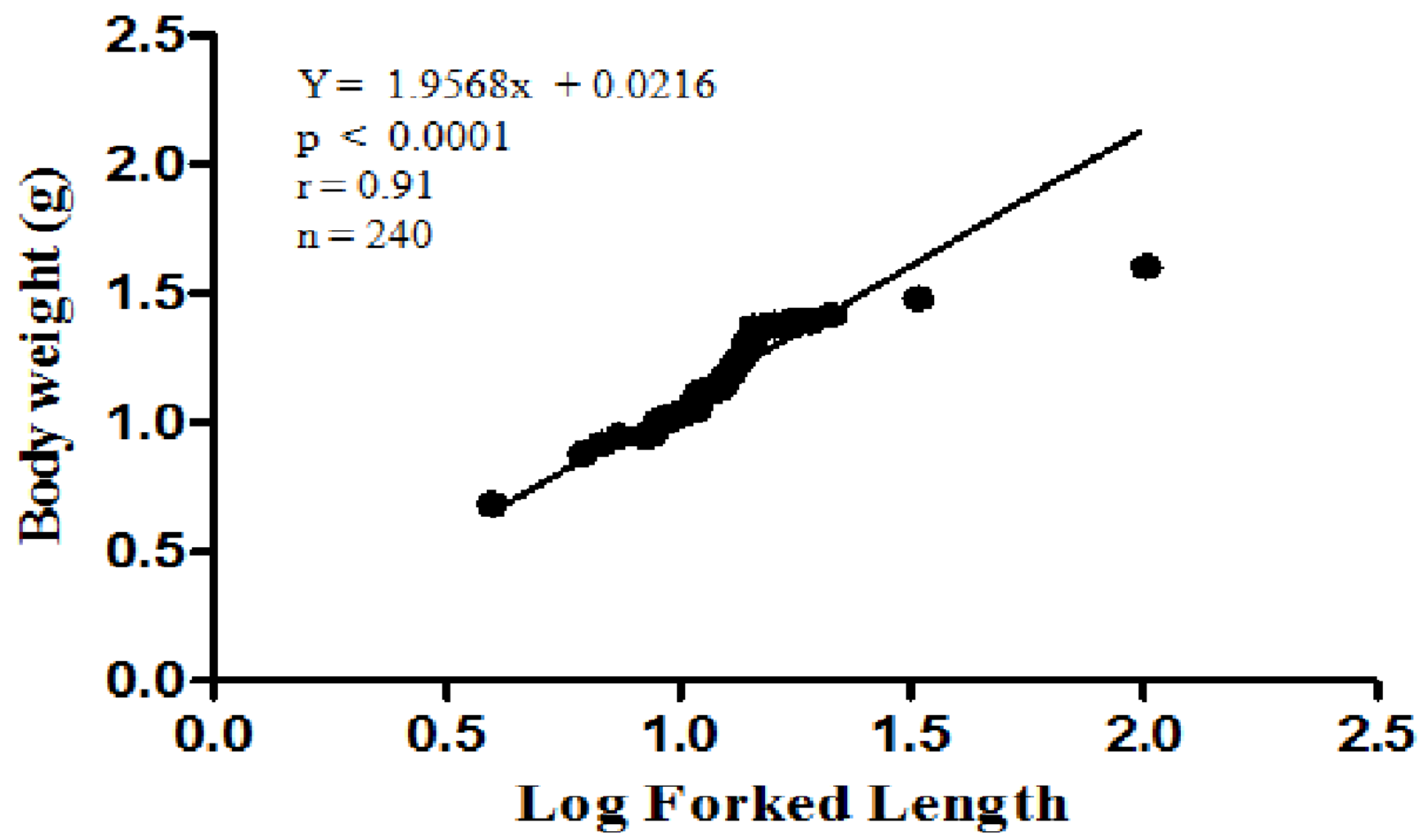

Figure 6: Length-weight relation of juvenile Chrysichthys nigrodigitatus from Epe Lagoon

\section{Discussion:-}

Diet compositions of juvenile stages of Chrysichthys nigrodigitaus from Epe Lagoon through the present study indicate that the species was an omnivorous; its diet comprised a wide spectrum of food items ranging from planktons, invertebrates, algae, plant and animal materials. When animals eat both plants and animal, they are called omnivores. These are often non-selective opportunistic feeders obtaining their food mostly by availability rather than preference. This feeding plasticity or the ability to change between alternative food resources would confer a great adaptation on omnivores such as juvenile $C$. nigrodigitaus to their local environment. Consequently, it may account for high domination of this species in the commercial catch of artisanal fishermen in Nigeria waters. Lévêque (1997) described omnivores as an important survival strategy over other fish species competing for a specific food item.

The result on diet composition in this study is similar to Bob-Manuel and Upadhi (2017) who reported stomach contents of juveniles of C. nigrodigitaus at Tombia Mangrove Swamp Creek, Rivers State, Nigeria. Based on both percentages occurrence and number, the authors reported dietary constituents including filamentous green algae (96 $\%, 24.67 \%)$, detritus and sand particles $(88 \%, 11.15 \%)$; insect parts constituted $(53 \%, 7.42 \%)$; mollusk $(51.5 \%$, $13.31 \%)$, bivalves $(49 \%, 10.17 \%)$; cladocerans $(48.5 \%, 11.32 \%)$; megalope larvae of crabs $(35 \%, 8.07 \%)$ for juveniles of $C$. nigrodigitaus. Ugwumba (1998) described juvenile $C$. nigrodigitaus as zooplankton feeders $(97.8 \%$, $83.97 \%$ ) based on number and frequency of occurrence respectively. Other food items she reported in the stomachs were insects $(1.1,17 \%)$, pisces $(1.6,4.2 \%)$, arachnida $(0.2,4.2 \%)$, and plant material $(0,4.2 \%)$

A clear morphological indicator of omnivorous feeding habits for Chrysichthys nigrodigitaus juvenile in Epe Lagoon was evidence in the Relative Gut Length (RGL) value (>1), which also categorized this species as omnivores. It is widely accepted consented that RGL $<1$ indicates carnivorous diet, $1<$ RGL 3 indicates omnivory, whereas values of RGL > 3 indicate diet based on plant material or detritus (Ward-Campbell et al. 2005). 
The relatively long intestine compares to body length in omnivores is an adaptation that provides a large surface area for digestion of hard plant tissues which constitutes part of its diet (Lalèyè et al. 2006).

The feeding strategy plot without ambiguities designates that juvenile Chrysichthys nigrodigitaus was insectivorous in Epe Lagoon. This was also corroborated by relative importance index of diet (Figure 4); insect being the most important food category. This showed the species is omnivores with preference for animal materials. Baras and Laleye (2003) opined that Chrysichthys spp, are benthic omnivores exhibiting a strong inclination to predation. Within the component of insect category, chironomid larvae were the most important insect in the diet. Developmental stages of insect may be the most desired diet for this stage of Chrysichthys nigrodigitaus. ZavalaCamin (1996) reported that insects play a significant role in fish diets in lagoons and rivers because they are present throughout the year. They are more available in the flood period which coincides with the breeding period of this species in the rainy season. Furthermore, several fish species have flexible diet which is an adaptation for utilizing available resources in the environment, only a few being strictly carnivorous or herbivorous (Lagler et al.(1977).

Recorded high correlation coefficient $(\mathrm{r}=0.91)$ indicate increase in length with weight. This agreed with other works on fish species from different water bodies (Froese, 2006). Estimated regression coefficient $b(=2)$ for juveniles of Chrysichthys nigrodigitaus in Epe Lagoon was within the expected range (2-4) for fishes (Bagenal and Tesch 1978; Froese, 2006). The value connotes that the juvenile stage $C$. nigrodigitaus commited more energy to growth in length than weights. This is in agreement with observation of Safran (1992) that small fishes increase in length at greater rate than they grow in other dimensions. When $b=3$, the fish grows isometrically resulting in ideal shape of fish. When it is less than 3.0, the fish experiences a negative allometric growth. The calculated form-factor was 0.0032 which ascribed a short and deep body forms for $C$. nigrodigitaus juvenile (Froese, 2006)

In conclusion, through the result of this study, juveniles Chrysichthys nigrodigitaus inhabiting Epe Lagoon are edacious omnivores with strong inclination for insectivorous feeding. This suggested that farm-raised juvenile $C$. nigrodigitaus will thrive on insect as protein source in their diet. Insect protein as feed meal or pellets may partly be substituted for fishmeal for the species because insect has been reported as an excellent source of proteins for several animal species. This study also validated the diet-intestine length relationship. Moreover, to my knowledge, there is no record of form-factor for $C$. nigrodigitaus juvenile in Nigerian waters; this study has provided a baseline data, therefore, bridging this gap in knowledge of this species.

\section{References:-}

1. Adite, A, Winemiller, K.O. and Fiogbe, E.D. 2006. Population structure and reproduction of the African bonytongue Silver Catfish in the So River-floodplain system (West Africa): implications for management. Ecology of Freshwater Fisheries 15: 30-39

2. Adite A, Megnisse, H., Gbaguidi, G. A. and Ategbo, J. 2017 Reproductive Biology and Life History Patterns of the Claroteid, Chrysichthys nigrodigitatus (Lacépède: 1803) from a Man- made Lake in Southern Benin. Journal of Fisheries and Aquatic Science 12: 106-116

3. Amundsen, P. A., Gabler, H-M., and Staldvik, F. J. 1996. A new approach to graphical analysis of feeding strategy from stomach contents data modification of Costello (1990) method. Journal of Fish Biology 43: 607614

4. Araoye, P.A. 1999. Spatio-temporal distribution of the fish Synodontis schall (Teleostei: Mochokidae) in Asa lake, Ilorin, Nigeria. Revista de Biología Tropical 47: 1061-1066.

5. Asuquo, P.E., U.I. Enin and Job, B.E. 2013. Ontogenetic variation in the diet of Chrysichthys nigrodigitatus (Lacepede, 1803) in a tropical estuarine ecosystem in Nigeria. Journal of Fisheries and Aquatic Sciences 8: 172-177.

6. Atobatele, O. E. and A. O. Ugwumba. 2011. Condition factor and diet of Chrysichthys nigrodigitatus and Chrysichthys auratus (Siluriformes: Bagridae) from Aiba Reservoire, Iwo, Nigeria. Revista de biologia tropical 59(3):1233-1244

7. Ayotunde, E.O. and Ada, F.B. 2013. Silver Catfish Chrysichthys nigrodigitatus (Lacepède, 1803), an endangered fish species in Cross River, Cross River state, Nigeria International Journal of Agricultural Science Research 2(3): 083-089

8. Bagenal, T.B. and Tesch, F.W. 1978. Methods of Assessment of Fish Production in Fresh Waters, IBP Handbook No 3, 3rd ed. Oxford Blackwell Scientific Publication, London.

9. Biswas, S.P., 1993. Manual of methods in fish biology. The South Asian publishers Pty ltd. 3 Nejati subhoshmary. Daryagam, New Dehli, India. 157P. 
10. Bob-Manuel, F. G. and Upadhi, F. 2017. Feeding Ecology of Juvenile Chrysichthys nigrodigitatus (Lacepede, 1803), at the Tombia Mangrove Swamp Creek, Rivers State, Nigeria. Continental Journal of Applied Science 12(1): 29-38

11. Bowen, S.H. 1984. Quantitative description of the diet. In: Fisheries techniques. Nielsen, L.A. \& D.L. Johnson (ed.): 325-336. American Fisheries Society. Maryland.

12. Boulenger, B. A. 1909-1915. Catalogue of fresh water fishes of Africa, British Museum. Natural History. Longmans Company Limited

13. Baras, E. and Lalèyè, P. 2003. Ecology and Behaviour of Catfishes. In : Arratia G., B.G. Kapoor, M. Chardon and R. Diogo (eds), Catfishes. Vol. 2, Science Publishers, Inc. USA. pp 525-579.

14. Chipps S. R. and Garvey, E. J. 2002. Assessment of Food Habits and Feeding Patterns, USGS South Dakota Cooperative Fish and Wildlife Research Unit, Department of Wildlife and Fisheries Sciences, South Dakota State University, Brookings, SD 57007.

15. Craig, J. 2000.. Percid Fishes. Sytematics, Ecology and Exploitation. 1st Edn. Blackwell Science, Oxford pp. 400

16. Euzen, O. 1987. Food habits and diet composition of some fishes of Kuwait. Kuwait Bulletin of Science 9:65-86

17. Ezenwa, B.I.O. and Kusemiju, K. 1981. Age and growth determination in the catfish, Chrysichthys nigrodigitatus (Lacepede) by the use of dorsal spine. Journal of Fish Biology 19(3): 345-351.

18. Ezenwa, B.I.O., Kusemiju, K. and Olaniyan, C.I.O. 1986. Comparative studies of the catfish, Chrysichthys nigrodigitatus (L) in three isolated geographical areas in Nigeria for breeding purpose. Aquat. Res. Afr. Reg. J. 1: $258-262$

19. FAO.1969. Fisheries survey in the western and mid-western regions of Nigeria. FAO/SF74/NIR6. http://www.fao.org

20. Froese, R. 2006. Cube law, condition factor and weight-length relationships: history, meta-analysis and recommendations. Journal of Applied Ichthyology 22(4): 241-253.

21. George, U. U. and Atakpa, E. O. 2015. Food and feeding Ecology of Chrysichthys nigrodigitatus in the Cross River estuary, South Eastern Nigeria. New York Science Journal 8(11):83-90

22. Houehanou, M.A.G., Adite, G. A. and Abou, Y. 2017. Trophic Ecology and Establishment of the Silver Catfish, Chrysichthys nigrodigitatus (Pisces: Siluriformes: Claroteidae) Introduced in an Artificial Pond of Benin, West Africa. Journal of Fisheries and Aquatic Science 12: 42-53

23. Hyslop, E. J. 1980. Stomach contents analysis: a review of methods and their application. Journal of Fisheries Biology 17:411-429.

24. Kusemiju, K. and Olaniyan, C. I. O. 1989. The length-weight relationship, condition factor and feeding habits of the catfish, Chrysichthys nigrodigitatus (L) in Lagos Lagoon, Nigeria. Nigeria Journal of Natural Science 4(1-2):144-149.

25. Lalèyè, P., Philippart, J. C. and Poncin, P. 1995. Reproductive biology of two species of Chrysichthys (Siluriformes, Bagridae) of Lake Nokoue and Porto Novo lagoon in Benin. Journal of African Zoology 109(3): 213-224

26. Lalèyè, P.Chikou, A., Gnohossou, P., Vandewalle, P., Philippart, J.C. and Teugels, G. 2006. Studies on the biology of two species of catfish Synodontisschall and Synodontis nigrita (Ostariophysi : Mochokidae) from the Ouémé River, Bénin. Belgium Journal of Zoology 136 (2) : 193-201

27. Lagler, K.F., 1956. Length-weight relationship and condition. In: Freshwater Fishery Biology. W.M.C. Brown Co., Dubuque, Lowa, $421 \mathrm{pp}$

28. Lagler, K.F, Bardach, J.E., Miller, RR. and Passino, D. R.M.., 1977. Ichthyology. New York: John Wiley \& Sons.

29. Lawal, M. O., O. J. Sangoleye, B. M. Seriki 2010. Morphometry and diet of Chrysichthys nigrodigitatus (Lac'epede) in Epe Lagoon, Nigeria. African Journal of Biotechnology 9(46):7955-7960.

30. Lévêque, C. 1997. Biodiversity dynamics and conservation: the freshwater fish of tropical Africa. Cambridge University Press, United Kindom, 438p

31. Olaosebikan, B.D., and Raji, A. 1988. Field guide to Nigerian freshwater fishes. FCFF, New Bussa, Bogu, Nigeria.

32. Otémé, Z. J. 1993. Reproduction and fecundity of the Mâchoiron Chrysichthys nigrodigitatus in breeding Journal of Ivoir. Océanol. Limnol. Abidjan, 1: 53-59.

33. Pauly, D. 1984. Fish population dynamics in tropicalwaters: a manual for use with programmable calculators.

34. Pinkas, L., M. S. Olipahnt, and I. L. K. Iverson 1971. Food habits of albacore, bluefin tuna, and bonito in Californian waters. Calif. Dep.Fish Game, Fishery Bulletin 152: 1-105. 
35. Reed W, Burchard J, Hopson AJ, Jenness J, Yaro I. 1967. Fish and Fisheries in Northern Nigeria. Ministry of Agriculture Northern Nigeria, Zaria, Nigeria. p. 226.

36. Safran, P. 1992. Theoretical analysis of the weight-length relationship in fish juveniles. Marine Biology 112: 545-551. 10.1007/BF00346171

37. Uneke, B. I. 2014. Diet composition, feeding habits and condition factor of Chrysichthys nigrodigitatus in Ebonyi River (A Tropical Flood River system) Southeastern Nigeria. Continental Journal of Agricultural Science 8(1):29-37.

38. Ward-Campbell B.M.S, Beamish F.W.H., Kongchaiya C.2005. Morphological characteristics in relation to diet in five coexisting Thai fish species. Journal of Fish Biology 67 (5): 1266-1279. DOI: 10.1111/j.10958649.2005.00821.X.

39. Yem, I. Y., N. O. Bankole, O. Oguntowora and B. Ibrahim. 2009. Food habit of the catfish Chrysichthys nigrodigitatus (Geoffrey Saint Hilasre 1808) in Kainji Lake, Nigeria. Natural Science 7:17-22.

40. Ugwumba, A.A.A. 1998. Food and feeding habits of juveniles of some culturable fish species in Nigeria Technical Paper 31 ISBN 987-2345-028

41. Zavala-Camin, L. A. 1996. Introduction to studies on natural fish feeding Maringa, Edeum, 129p 